\title{
Archives of Environmental and Occupational Health

The Contribution of the Clinica del Lavoro to the Development of Industrial Hygiene and Toxicology in the Twentieth Century

\begin{tabular}{|r|l|}
\hline Journal: & Archives of Environmental and Occupational Health \\
\hline Manuscript ID & $11-18-126$. R1 \\
\hline Manuscript Type: & Full-length manuscript \\
\hline Keywords: & $\begin{array}{l}\text { History, industrial hygiene, industrial toxicology, environmental toxicology, } \\
\text { Clinica del Lavoro, Milan }\end{array}$ \\
\hline \multicolumn{2}{|l}{}
\end{tabular}

SCHOLARONE ${ }^{\text {m }}$

Manuscripts 


\begin{abstract}
In 1910, the founder of the Clinica del Lavoro of Milan, Luigi Devoto established a chemistry laboratory in the new institute, sustaining its importance in the study of occupational diseases. In 1948, the new director of the Clinica, Enrico C. Vigliani established the first laboratory of industrial hygiene in Italy, in the years of the economic boom. In 1960s, this laboratory, directed by Nicola Zurlo, significantly contributed to the research in the field. In 1980s and 1990s, the laboratory of the Clinica started to explore the field of environmental toxicology, studying the effects of benzene and other traffic pollutants on the general population. The analysis of history of the Clinica del Lavoro of Milan may represent a valuable tool for studying the origin and the development of industrial hygiene, occupational and environmental toxicology in the twentieth century.
\end{abstract}

\title{
Keywords:
}

industrial hygiene; industrial toxicology; environmental toxicology; Clinica del Lavoro; Milan; history 
The "Clinica del Lavoro", established in Milan at the beginnings of the twentieth century, was the first institute in the world to be devoted to the scientific study and the treatment of work-related diseases, becoming a model for similar institutions in Moscow (1923) and in Berlin (1925). ${ }^{1}$ Under the direction of Luigi Devoto (1864-1936), Luigi Preti (1881-1941), and Enrico C. Vigliani (19071992), the Clinica del Lavoro significantly contributed to the development of the scientific research in all the fields of Occupational Health. ${ }^{1}$ The aim of this historical paper is to analyze the evolution of the industrial hygiene and toxicology during the twentieth century throughout the contributions provided by the Clinica del Lavoro of Milan to the international research in these fields.

\section{The chemistry laboratory in the Clinica del Lavoro (1910-1950)}

When the Clinica del Lavoro was inaugurated in 1910, its founder, Luigi Devoto, established a chemistry laboratory on its first floor, above the entrance (Figure 1). ${ }^{2}$ The laboratory was able to support the physicians, providing chemical analyses on biological fluids of their hospitalized patients. When Devoto decided to establish a chemistry laboratory in his new institute, he had a pioneering idea. Indeed, in that period the clinicians were used to conducted basic chemical analyses in their own medical offices or in a small room in the wards without the support of specialized technicians. Clinical pathology was nothing more than simple examination of the urine and blood count. ${ }^{3}$ Only great hospitals in the United States and in the United Kingdom had their own laboratories, where chemists were employed to provide help to clinicians in analysis.

However, even in these countries the clinical laboratories not always accorded the respect their importance deserves. A comment, made in 1918, well describes their conditions: "Usually after the hospital has been completely erected, certain space, unsuitable for any other purpose, is assigned to the laboratory. It is thus that we find this department frequently located in basements, in out of the way nooks and corners, in outhouses or roof structures built as an afterthought. The laboratory is gloomy, the ventilation unsuitable, and the general conditions such as to make the scientist working 
there cognizant of a spirit of depression in his assistants and help". ${ }^{3}$ Luigi Devoto actually believed that the chemistry laboratory also had a decisive role in the comprehension of physio-pathogenic mechanisms of occupational diseases and in their treatment. This different consideration is demonstrated by the fact that he placed the laboratory on the first floor of the institute, in wellventilated and bright rooms. Devoto sustained that chemistry laboratory had to "examine the substances commonly used by the workers and analyze the components of the air in workplaces". 2 It had to evaluate "the effects of occupational toxins on the functions of human organism".2 With these considerations, Devoto seems to outline the objectives of a modern laboratory of industrial hygiene and toxicology. So, it does not come as a surprise that the first international technical conference on industrial hygiene was organized by Luigi Devoto in Milan on May 1912. The director of the Clinica del Lavoro invested many funds in equipment for modernizing his laboratory; up to 12 chemists could simultaneously work in the laboratory. ${ }^{2}$ Initially, the physician Luigi Preti (1881-1941) and the chemist Monti co-directed the laboratory, while since the end of the 1920s the head of the laboratory was the chemist Giovanni Battista Lo Faso. In 1928 Lo Faso published a paper on a pioneering method of determining the concentration of mercury in human urine $^{4}$ and, in collaboration with the pathologist Giorgio Boattini, he also wrote a considerable paper on lung anthracosis of coal-miners, determining carbon and iron in the pulmonary tissues of workers affected by this occupational disease. ${ }^{5}$

In the following years, the Clinica del Lavoro, directed by Luigi Preti after the death of Devoto, continued its studies in the field of occupational toxicology. In detail, the chemistry laboratory developed new methods for determining concentration of lead in urine, blood and saliva. ${ }^{6-9}$ All these studied demonstrated the elevated interest towards occupational toxicology and industrial hygiene in the "Clinica del Lavoro" in the first thirty years of its activity. Preti and his collaborators mainly focused on classical occupational toxics and, in particular, on the determination of mercury and lead in body fluids. Indeed, in that period, scientists and physicians were looking for highsensitive methods for early diagnosis of occupational poisoning. It should be also note that the 
direction of the chemistry laboratory, initially managed by a physician (Preti), was given to a chemist (Lo Faso), so valuing the role of this figure in a clinical and research institute.

Finally, the first decades of the chemistry laboratory of the "Clinica del Lavoro" demonstrate that initially there were not separate laboratories dedicated to toxicology and to clinical pathology for hospitalized patients, but there was a general chemistry laboratory, in which different topics were analyzed and studied without distinctions.

Industrial Hygiene in Milan in the postwar economic boom (1950-1970)

The-War World II limited the research of the Clinica del Lavoro, which suffered significant damages as a result of the Allied bombing of Milan in 1943. In the same period, the institute changed its director after the early and unexpected death of Luigi Preti. In 1942, Enrico C. Vigliani was appointed as new director of the Clinica, but his first problem was to deal with the reconstruction of the institute, whichthat was completed in $1947 .^{10-11}$

In the post-war period, the Italian economy was booming, with record high growth rates and the development of new and old industries. The increase of production of Italian factories determined a rise of work-related accidents and occupational diseases, so various industries seek the medical and scientific support of the Clinica del Lavoro in preventing, identifying and treating health problems related to work. ${ }^{10}$ In that period, Montecatini was the giant of Italian industrial chemistry and its headquarter was in Milan, which was the leading industrial city of Italy. The "Società Anonima delle Miniere di Montecatini" was founded in 1888 in Tuscany, having its roots in the mining industry (copper mines). After the discovery of pyrite in Tuscany, Monecatini started to produceproduct sulfuric acid; it later produced ammonia, becoming known for its widely used process for fertilizer production. In 1947 Enrico Vigliani was requested by Mario Barsotti - director of Occupational Health Service of Montecatini - to conduct a study on bladder cancers among workers of an azo dye factory belonging to the big chemical industry of Montecatini. ${ }^{10}$ In 1948 , 
Barsotti and Vigliani showed the first results on mortality for bladder cancer by azo dye during the Conference of International Society of Occupational Health in London. ${ }^{11-12}$ The scientific achievements led Montecatini, together with INAIL (Italian Workers' Compensation Authority), to make funds available for establishing an industrial hygiene laboratory in Clinica del Lavoro. So in 1948 Vigliani could inaugurate the first industrial hygiene laboratory in Italy within the "Clinica del Lavoro" of Milan (Figure 2), nominating the young chemist Nicola Zurlo (1916-1990) as head of the new laboratory. ${ }^{10}$ At the same time, in 1949, Vigliani appointed Raoul Grisler (1922-2010) as director of chemistry laboratory with the aim of transforming it into a modern clinical laboratory, that could provide clinical analysis not only for the Clinica del Lavoro, but also for all the hospitals in Milan. ${ }^{10}$ The industrial hygiene laboratory of Zurlo (supported by Montecatini and INAIL) and the biochemistry laboratory of Grisler (supported by Clinica del Lavoro) were never in contrast with each other; rather they collaborated on many topics.

The first works of the new laboratory of industrial hygiene were on metal intoxications. In particular, at the beginningbeginnings of the 1950s Zurlo focused on lead determination in biological material and on chronic mercury poisoning in a manufacture of luxury hats in Alessandria (Northern Italy). ${ }^{13-14}$ Lead intoxication was another issue well developed in that period. $^{15-18}$ IndustrialThe industriat hygienists of the Clinica del Lavoro also developed new methods for determining silica in the environment and proposed masks and other devices to avoid or minimize exposure to dust in the workplace. ${ }^{19-25}$ In that period, the team started to investigate on the health effects of organophosphate insecticides, which were an emerging problem in rural world $^{26-27}$ It is interesting to note that in 1950s the Clinica del Lavoro also conducted pioneering studies on air pollution, developing methods for monitoring toxic fumes and vapors in the atmosphere. $^{28-31}$ In the same years, the chemistry laboratory of Grisler conducted studies on biochemical alterations in workers affected by silicosis and on the intoxication by trichloroethylene. ${ }^{32-36}$ 
During the 1960s, the laboratory of industrial hygiene greatly expanded.had a great development. The European Coal and Steel Community (ECSC) and INAIL made available funds for studying pneumoconiosis and its prevention. In that period, Vigliani was able to purchase a "Siemens Elmiskop I" electron microscope - the first at the University of Milan - sponsored by INAIL. ${ }^{11}$ Furthermore, the Clinica del Lavoro signed an agreement with INAM ("Instituto Nazionale di Assicurazione contro le Malattie", National Institute for Insurance Against Sickness), the most important mutual fund in Italy at that time. ${ }^{10}$ In detail, the clinical pathology laboratory of the Clinica del Lavoro, directed by Grisler, agreed to provide laboratory analysis for all the patients of INAM in Milan, so the Clinica del Lavoro started to provide laboratory analysis for 400 patients a day, reaching over 400,000 patients in a year at the end of 1960s. Thanks to huge economic funds derived from these new incomes, in 1963 the industrial hygiene laboratory was moved in a new modern structure ("Padiglione FEAL") built next to the old edifice of the Clinica. ${ }^{10}$ Furthermore, economic resources also allowed the recruitment of new staff: the Clinica del Lavoro were able to hire personnel: chemists, engineers, technicians and physicians. The laboratory was equipped with the most update instrumentation, such as X-ray diffractometer for the analysis of the structure of crystals in powders and fibers, gas-chromatographs with flame ionization and electron capture detector for the analysis of volatile organic compounds in air samples and industrial products, graphite furnace and flame atomic absorption spectrometry for the measurements of metals in environmental and biological samples, UV/Visible spectrometry, phase contrast microscopy for the analysis of silica particles and asbestos and glass fibers.

In that period, Gianmarco Cavagna, one of the most important Italian industrial toxicologists of that period, conducted several studies on byssinosis. ${ }^{37-40}$ In the same period, in the Clinica del Lavoro, Vito Foà and Carla Antonini, demonstrated the presence of endotoxins in the atmosphere of a cotton carder, ${ }^{41}$ supporting that the pathogenesis of byssinosis was based on endotoxin and anticipating studies of Rylander. ${ }^{42}$ Furthermore, Cavagna developed pioneering researches on health effects of insecticides and carbon disulfide. ${ }^{43-50}$ Zurlo, Cavagna and their team also wrote several 
contributions on lead intoxications, pneumoconiosis and toxics in atmosphere and at the workplace. $^{51-62}$ In this context, Zurlo invented a valuable mercury clepsydra vacuum pump to measure concentrations of atmospheric dusts by counting particles, internationally known as "Zurlo's pump". ${ }^{63}$ The Clinica del Lavoro conducted several studies on industrial and environmental toxicology on nitroglycol and nitroglycerine (and its correlation with "Monday disease"), trichloroethylene, polytetrafluoroethylene, indene, penicillin, sodium hypochlorite (liquid bleach) and on zinc-fume fever. ${ }^{64-80}$ General papers on the development of industrial hygiene, its role and its problems were also published. ${ }^{81-85}$ Works by Grisler on diagnosis and treatment of lead intoxication and on the development of other biomarkers related to occupational exposures are also noteworthshould be mentioned. ${ }^{86-95}$

In this period, the Clinica del Lavoro introduced a new approach to the problems of industrial hygiene in factories, through interventions directly agreed with the workers in the factory assemblies. It was not infrequent to see Zurlo and his collaborators talking with the workers of the factories in which they conducted their studies. The medical and technical staff of the Clinica del Lavoro could collect samples and radiological investigations on the workers directly in the workplace, also thanks to the presence of laboratory and radiology mobile units. ${ }^{96}$ The glorious twenty-year period of industrial hygiene and toxicology in Milan reached its peak in 1969, when Zurlo founded the Associazione Italiana Degli Igienisti Industriali (AIDII), the first Italian association for industrial hygienists. ${ }^{10}$

\section{The crisis and the new development (1970-2000)}

In July 1970, the Clinica del Lavoro was dismayed by the fact that Gianmarco Cavagna suddenly died during an experiment on the health effects of dibromotetrafluoroethane, a new chemical product developed by Montecanini for fire suppression systems. ${ }^{10}$ Furthermore, the researchers conducted by Cavagna himself on the effects of dichlorvos - an organophosphate, widely used as an 
insecticide - on the levels of plasma and erythrocyte cholinesterase (ChE) activities in 22 newborn babies were judged inappropriate by mass media and public opinion. ${ }^{47}$ In the meantime, student protests spread to the University of Milan and targeted Enrico Vigliani and his collaborators, accusing them of colludingbeing colluded with the employers and industry magnates..$^{10}$ TheseThe protests and some alleged economic scandals forced Vigliani to move away from Italy in 1971, so he decided to continue his studies in South Africa and Turkey. ${ }^{11}$ The Clinica del Lavoro remained without a direction until 1977. In the first years of 1970s, the institute apparently continued the studies developed in previous decades. The works published in the period 1970-1977 were on lead intoxication, silicosis, general industrial hygiene and toxicology of cotton dusts, even if a decreasing trend in the scientific productivity was observed. ${ }^{97-116}$

Another event that revolutionized the life of the Clinica del Lavoro was the Seveso disaster. It was an industrial accident eccurred-in July 1976 in a small chemical manufacturing plant approximately 20 kilometers north of Milan, resulting in the highest known exposure to dioxin (TCDD) in | residential populations. ${ }^{117}$ Nicola Zurlo was appointed as responsible for monitoring the sampling of dioxin in Seveso, so he moved away from the Clinica del Lavoro, together with some collaborators such as Gianfranco Peruzzo and Carlo Sala. ${ }^{10}$ In the same year, Montecatini renamed as Montedison - transferred its own personnel and equipment to other laboratories. These changes were the opportunity to create a new team of industrial hygienists and toxicologists. ${ }^{10}$

At the end of the 1970s, the new director of the Clinica del Lavoro, Gerolamo Chiappino (19332016), requested Vito Foà - who wasthe responsible for theef toxicology division - to reorganize the laboratory of industrial hygiene. Foà, who had started to work in the industrial hygiene laboratory of the Clinica del Lavoro since 1958, could make use of skills and experience of old and new colleagues such as Antonio Colombi, Marco Maroni (1949-2006), Gianfranco Peruzzo, Mario Patroni, Francesca Andreoletti, and Marina Buratti . In the following decade, the Clinica del Lavoro again began to develop important scientific research in the field of industrial hygiene and toxicology. In detail, the laboratory conducted studies on a large number of different substances: 
carbon disulfide, aromatic ammines, chromium, dimethylformamide, vinyl chloride, asbestos, and n-hexane. ${ }^{118-131}$ In this period, Foà, Colombi and Maroni proposed to use the determination of $\mathrm{d}$ glucaric acid and of the pattern of urinary porphyrins as indicators of effect for exposure to chemical substances. ${ }^{132-135}$ The same authors, in collaboration with Marina Buratti, developed an analytical method for speciation of urinary arsenic in order to distinguish occupational and alimentary exposure. ${ }^{136-139}$ Classical metal intoxication (lead and mercury) and exposure to dusts continued to be investigated. ${ }^{140-142}$ The team monitored workers' exposure in the production plants of 1,3-butadiene and conducted a survey on pentachlorophenol in wood industry. ${ }^{143}$ It should be also mentioned the large number of studies on polychlorinated biphenyls, especially at the end of 1970s and the beginnings of 1980s. ${ }^{144-149}$ At the end of the 1970s, new Occupational Health Units were established in the cities around Milan, where physicians - who have studied and have worked in the Clinica del Lavoro - started to work and to conduct scientific researches. In particular, the institute of Milan collaborated with Occupational Health Units of Lecco (Sergio Zedda, Carlo Sala and Angelo Maria Cirla) and Desio (Italo Ghezzi and Franco Toffoletto). These collaborations were mainly developed by Lorenzo Alessio on intoxication from metals, in particularly lead, cadmium and other metals; in these studies the association of clinical signs and new indicators - including Zinc protoporphyrin, ZPP, recently discovered - was investigated. ${ }^{150-162}$

In 1980s, the intense work on biomonitoring conducted at the Clinica del Lavoro and in other European institutes prompted the Commission of the European Community to start the publication of the series on biological indicators for the assessment of human exposure to industrial chemicals. In the 1990s the researchers of the Clinica were actively involved in the works of the new born "Scientific Committee on Occupational Exposure Limits" (SCOEL) of the European Commission. In the meantime, Enea Occella (1928-2011) from Polytechnic University of Turin continued to collaborate with the Clinica del Lavoro in researches on asbestos. These works, specially developed with Mario Patroni, played a determinant role in the enactment of Italian asbestos legislation and in the identification of its limit values. ${ }^{163}$ 
Among the works on general concepts of industrial hygiene and toxicology, ${ }^{164-167}$ the paper by Vito Foà published in 1989 well describesevidences the shift of classical industrial hygiene towards an occupational and environmental hygiene. ${ }^{168}$ This transformation is also supportedtestified by the foundation of the International Center for Pesticide Safety by Marco Maroni in 1990. ${ }^{169-170}$ Furthermore it should be mentioned the works by Patroni on asbestos fibers and their concentration in the atmosphere. ${ }^{171-173}$ At the beginning of the 1990s new environmental and toxicological issues associated with air pollution due to traffic emissions concerned occupational and public health. New

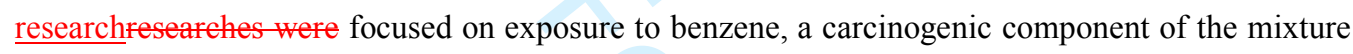
of aromatic hydrocarbons used to increase the gasoline anti knocking power, after the ban of leaded gasoline in Italy, using air and biological monitoring. ${ }^{174-178}$ Other pollutants arising from traffic, such as particulate matter and polycyclic aromatic hydrocarbons were also investigated, as well as the indoor air quality. ${ }^{179-184}$ Nevertheless, classic occupational toxicology issues continued to be investigated. ${ }^{185-187}$ The lowering of occupational exposure limits, and the necessity of monitoring exposure to chemicals in the general population prompted the researchers of the Clinica del Lavoro to investigate new biomarkers of exposure using very specific and sensible assays based on novel techniques such as mass spectrometry.

\section{Conclusions}

The history of laboratories of Industrial Hygiene and of Toxicology of the Clinica del Lavoro of Milan shows the development of these disciplines during the twentieth century. Luigi Devoto had the pioneering idea to establish a chemistry laboratory in his institute, since he believed that the laboratory was a valuable tool for investigating the pathogenesis and the treatment of occupational diseases. In the first decades of the century, the laboratory focused its researches towards intoxications by metals and, particularly, lead intoxication. In the period after WWII, the Italian economic boom led the Clinica del Lavoro, directed by Vigliani, to implement the laboratory activities, thanks to the support of some largebig chemical industries (Montecatini), INAIL and 
mutual funds. In that period, the laboratory of Industrial Hygiene directed by Nicola Zurlo developed researches in different fields, such as silicosis, dusts, organophosphate insecticides, occupational toxicology, achieving relevant results. It should be mentioned the studies by Gianmarco Cavagna on pathogenesis of byssinosis based on endotoxins. Agriculture and industry appeared as the principal fields of interest for industrial hygienists and toxicologists. In the 1980s, modifications in the productive sectors in Italy, as well as in the other industrialized countries, led to a deep change also in the research of the Clinica. In detail, alongside the classic occupational issues, the laboratory began to deal with environmental toxicology, focusing on the effects of environmental toxics (e.g. benzene and polycyclic aromatic hydrocarbons arising from traffic) on general population and developed the new issue of indoor air quality. It should be also noted that the scientific works of the Clinica of that period were mostly published on "La Medicina del Lavoro". This scientific journal - the oldest regular periodical of Environmental and Occupational Health, originally founded in December 1901 as "Il Lavoro" by Luigi Devoto and Carlo Moreschi $\underline{(1876-1921)^{188-189} \text { - may therefore be a precious source of information for studying the }}$ development of industrial hygiene and occupational toxicology in those years. In conclusion, the laboratories of the Clinica del Lavoro mirror the worldwide development of industrial hygiene and occupational and environmental toxicology in the last century, representing for many years an international reference point for the discipline, in Italy and worldwidein the all industrialized eountries.

\section{Acknowledgements}

The authors would like to thank the following individualsthank for all the information on the life of the laboratory of Industrial Hygiene and Toxicology of the Clinica del Lavoro: Vito Foà, Lorenzo Alessio, Marina Buratti, Laura Campo, Paolo Carrer, Andrea Cattaneo, Domenico Maria Cavallo, Giancarlo Cesana, Angelo Maria Cirla, Antonio Colombi, Antonia Francesca Franchini, Rosario Giampiccolo, Giovanni Molteni, Oronzo Pellegrino, Gianfranco Peruzzo, Alessandro Porro, Carlo 
Sala, Franco Toffoletto, Rosario Trimarchi, Domenico Xais, Carla Valla. Finally, the authors thank the Archivio Edison (Centro per la cultura d'impresa) for photographic documentation.

References

1. Bertazzi PA, Foà V. The first century of the "clinica del lavoro" in Milan. Int J Occup Environ Health. 2005;11:12-17.

2. Devoto L. La Clinica del Lavoro di Milano. Venti anni (1910-1929). Milano: Clinica del Lavoro, 1929.

3. King LS. XII. Clinical laboratories become important, 1870-1900. JAMA 1983;249:30253029.

4. Lo Faso GB. Sulla ricerca di tracce minime di mercurio nelle urine e nei liquidi organici. Milano: Cordani, 1928

5. Boattini G, Lo Faso GB. Sulla essenza dell'antracosi polmonare. Med Lav 1928;12:545-53

6. Massione R. Sui metodi di ricerca del piombo nei liquidi organici. Milano: Cordani, 1932

7. Preti L, Maugeri S. Sopra un metodo semplice per la determinazione del piombo nelle urine. Milano: Cordani, 1936

8. Massione R. Sulla determinazione del piombo nel sangue. Milano: Cordani, 1940

9. Seghini C. Il piombo nella saliva di individui normali e saturnini. Milano: Cordani, 1941

10. Vigliani EC. Storia e ricordi di 80 anni di vita della Clinica del Lavoro di Milano. Med Lav. $1992 ; 83: 33-55$

11. Riva MA, Carnevale F, D'Orso MI, Iavicoli S, Bertazzi PA, Cesana G. The contribution of Enrico C. Vigliani (1907-1992) to the international development of occupational medicine and industrial hygiene. Med Lav. 2012;103:419-426.
Formatted: Font: Italian (Italy)

Formatted: Font: Italian (Italy) 
12. Barsotti M, Vigliani EC. Bladder lesions from aromatic amines; statistical considerations and prevention. Arch Ind Hyg Occup Med. 1952;5:234-241

13. Baldi G, Vigliani EC, Zurlo N. Il mercurialismo nei cappellifici e sua prevenzione. Med Lav. 1952; 43:367-368

14. Baldi G, Vigliani EC, Zurlo N. Il mercurialismo cronico nei cappellifici. Med Lav. $1953 ; 44: 161-198$

15. Vigliani EC, Zurlo N. The effects of BAL on the metabolism of lead and on the symptomatology. Br J Ind Med. 1951;8:218-225

16. Saita G, Zurlo N, Gattoni L. Colica saturnina seguita dopo pochi giorni da morte dosaggio del piombo negli organi. Med Lav. 1954;45:379-385

17. Zurlo N, Meschia E. Microdeterminazione titrimetrica del piombo con ditizone nell'aria e nei materiali biologici. Med Lav. 1954;45:668-674

18. Parmeggiani L, Zurlo N. Sul rischio di saturnismo nelle operazioni di trafileria e di tempra a piombo. Med Lav. 1955;46:176-184

19. Peretti L, Parmeggiani L, Occella E, Zurlo N. La determinazione della pericolosità agli effetti della silicosi nelle lavorazioni polverose. Med Lav. 1952;43:376-377

20. Gerosa G, Ghiringhelli L, Griffini A, Molina C, Pasargiklian M, Zurlo N. Studio della idoneità di due maschere antipolvere a proteggere i lavoratori contro la silicosi. Med Lav. $1952 ; 43: 391-417$

21. Troisi FM, Zurlo N. Sul rischio della silicosi in rapporto a polverosità ambientali di SiO2 ed anzianità di lavoro in una fabbrica di ceramica. Med Lav. 1954;45:614-623

22. Zurlo N, Griffini AM. Determinazione chimica del quarzo nei minerali e nelle polveri. Med Lav. 1954;45:675-691

23. Zurlo N, Sartorelli E. Studio sull'efficienza e la tollerabilità di due nuovi apparecchi per la protezione dei lavoratori dalle polveri nocive. Med Lav. 1955;46:335-351 
24. Frigerio G, Zurlo N. Procedimento rapido di analisi di routine per la determinazione del quarzo per via debyegrafica e chimico-petrografica. Med Lav. 1955;46:549-558

25. Occella E, Zurlo N, Frigerio G. Metodiche di analisi della silice libera cristallina. Med Lav. $1957 ; 48: 604-612$

26. Zurlo N, Sassi C, Metrico L. Determinazione della attività anticolinesterasica e della massima concentrazione tollerabile nell'atmosfera inquinata da insetticidi organici fosforati. Med Lav. 1954;45:533-543

27. Sassi C, Zurlo N, Bartalini E, Metrico L. L'intossicazione subacuta de parathion: importanza dell'assorbimento percutaneo nell'esposizione professionale e sua prevenzione; studio di un episodio di intossicazione collettiva professionale. Med Lav. 1955;46:251-269.

28. Zurlo N, Griffini AM. Note sulla determinazione della formaldeide nell'aria. Med Lav. 1954; $45: 692-694$

29. Zurlo N. I metodi di controllo dei fumi e vapori tossici nell'atmosfera. Med Lav. 1957; 48:200-202

30. Vigliani EC, Zurlo N. Composizione chimica e granulometrica del pulviscolo in sospensione nell'atmosfera di un'area ospitaliera di Milano. Med Lav. 1958;49:163-166

31. Vigliani E, Frigerio G, Zurlo N. Metodi per la determinazione degli inquinanti solidi dell'atmosfera. Minerva Med. 1958; 49, 23:1063-1066

32. Capellini A, Grisler R. Studio della funzionalità epatica in un gruppo di operai cronicamente intossicati da tricloroetilene. Med Lav. 1958;49:167-172.

33. Grisler R, Gallina R. Il tricloroetilene. Med Lav. 1956;47:240-262.

34. Raule A, Brina A, Grisler R. Rilievi e considerazioni sul risentimento cardiovascolare nella silicosi. Med Lav. 195;44:416-419.

35. Raule A, Grisler R. Sui valori dell'androgenuria nei silicotici. Med Lav. 1951;42:337-343.

36. Raule A, Grisler R. La funzionalità corticosurrenale nei silicotici. Med Lav. 1950;41:243246. 
37. Cavagna G, Finulli M. Histamine-liberating activity in the subcutaneous tissue of rats of endotoxins containing cotton. Med Lav. 1961;52:43-46

38. Cavagna G. Effetto sensibilizzante di un estratto di semi di tamarindo usato come bozzima per tessitura. Med Lav. 1966; 57:241-248

39. Foà V, Zedda S, Cavagna G. Significato e limite delle prove di funzionalità respiratoria nello studio della bissinosi. Indagine condotta in un cotonificio della Lombardia. Med Lav. $1967 ; 58: 321-332$

40. Cavagna G, Foà V, Vigliani EC. Effects in man and rabbits of inhalation of cotton dust or extracts and purified endotoxins. Br J Ind Med. 1969;26:314-321

41. Foa V, Zedda S, Cardani A, et al. Patologia da fibre tessili vegetali. Med Lav. 1975;66:527572

42. Rylander R. Bacteria as etiological agents in byssinosis and other lung disease. Eur J Respir Dis Suppl. 1982;123:34-46.

43. Cavagna G, Bartalini E. La prevenzione ed il trattamento dell'intossicazione da insetticidi fosforati organici. Med Lav. 1965;56:337-356

44. Cavagna G, Locati G. Evaluation des résultats de l'activaté cholinestérasique hématique chez les sujets exposés aux insecticides organo-phosphorés. Ann Biol Clin (Paris). 1968;26:1003-1010.

45. Locati G, Cavagna G. Valori normali di attività colinesterasica ematica determinati con metodo titrimetrico automatico. Med Lav. 1968;59:516-521

46. Cavagna G, Locati G, Vigliani EC. Clinical effects of exposure to DDVP (vapona) insecticide in hospital wards. Arch Environ Health. 1969;19:112-123

47. Cavagna G, Locati G, Vigliani EC. Exposure of newborn babies to "vapona" insecticide. Eur J Toxicol. 1970;3:49-57

48. Cavagna G, Vigliani EC. Problemes d'hygiene et de securitè dans l'emploi du Vapona comme insecticide dans les locaux domestiques. Med Lav. 1970; 61:409-423 
49. Locati G, Cavagna G, Bugatti A. Study on the penetration of phosdrin through protective gloves. Med Lav. 1968; 59:342-345

50. Cavagna G. La valutazione biologica della esposizione al solfuro di carbonio. Med Lav. $1967 ; 58: 241-244$

51. Bartolozzi O, Zurlo N. Effects of prophylaxis with versenate calcium in workers exposed to lead. Med Lav. 1960; 51:607-611

52. Zurlo N, Griffini AM, Colombo G. Determination of lead in urine by atomic absorption spectrophotometry after coprecipitation with thorium. Anal Chim Acta. 1969; 47:203-208

53. Grisler R, Farina G, Zurlo N, Molteni G. L'impiego del versene per via intramuscolare e a basso dosaggio per il trattamento del saturnismo. Med Lav. 1969;60:288-296

54. Cavagna G, Beard RR. Potassium loss from lead-poisoned erythrocytes. failure to demonstrate correlation with age of cells. Med Lav. 1962;53:779-781

55. Zurlo N, Metrico L. Simple methods for microdetermination of industrial toxics in air. Med Lav. 1960;51:241-358

56. Zurlo N. Measurement of the sulphur trioxide content of the air. Med Lav. 1962;53:325-329

57. Zurlo N, Griffini AM. Measurement of the SO2 content of the air in the presence of oxides of nitrogen and heavy metals. Med Lav. 1962;53:330-335

58. Cavagna G, Amante L, Finulli M. Action of a lathyrogenic substance (aminoacetonitrile sulfate) in experimental silicosis. Med Lav. 1962;53:714-721

59. Cavagna G, Nichelatti T. The protective influence of polyvinylpyridine-N-oxide in experimental silicosis. Med Lav. 1963;54:621-627

60. Pernis B, Vigliani EC, Cavagna G. Experimental induction of a rheumatoid factor by means of quartz dust. Grundfragen Silikoseforsch. 1963;6:369-372

61. Foà V, Grieco A, Zedda S. Indagine clinico-radiologica sull'incidenza della pneumoconiosi fra gli operai addetti alla fabbricazione di elettrodi di carbone. Med Lav. 1966;57:684-695

62. Foà V. La pneumoconiosi dei pulitori di oggetti metallici. Med Lav. 1967; 58:588-602 
63. Zurlo N. Counting of atmospheric dusts using millipore filters. Med Lav. 1960;51:660-671

64. Zurlo N, Conti M, Nichelatti T. Fractional determination of nitroglycerine and nitroglycol in biological liquids. Med Lav. 1963;54:166-168

65. Secchi GC, Chiappino G, Lotto A, Zurlo N. Composizione chimica attuale delle trieline commerciali e loro effetti epatotossici. Studio clinico ed enzimologico. Med Lav. 1968; 59:486-497

66. Capellini A, Chiappino G, Zurlo N. Osservazioni cliniche e sperimentali sulle polineuriti cosidette da tricresilfosfati. Med Lav. 1968;59:721-759

67. Pernis B, Vigliani EC, Cavagna G, Finulli M. Endogenous pyrogen in the pathogenesis of zinc-fume fever. Med Lav. 1960;51:579-586

68. Cavagna G, Finulli M. Pyrogenic effect of $\mathrm{ZnO}$ by the intravenous route. Med Lav. $1961 ; 52: 127-131$

69. Cavagna G, Finulli M, Vigliani EC. Experimental study on the pathogenesis of fevers caused by the inhalation of teflon (polytetrafluoroethylene) fumes. Med Lav. 1961;52:251261

70. Vigliani EC, Cavagna G, Finulli M. On the mechanism of pyrogenic action of finely particulate materials. Med Lav. 1961; 52:641-648

71. Pernis B, Cavagna G, Finulli M. Phagocytosis in vitro of particles with pyrogenic action. Med Lav. 1961; 52:649-652

72. Cavagna G, Locati G, Capizzi M. Studio sul metabolismo delle catecolamine nella intossicazione sperimentale cronica da nitroglicole. I. Il contenuto di catecolamine nel miocardio. Med Lav. 1968;59:772-777

73. Locati G, Cavagna G, De Micheli P. Studio sul metabolismo delle catecolamine nella intossicazione sperimentale cronica da nitroglicole. II. L'attivita' monoaminossidasica nel miocardio e nel cervello. Med Lav. 1968;59:778-783 
74. Bartalini E, Cavagna G, Foà V. Epidemiological and clinical features of occupational nitroglycol poisoning in italy. Med Lav. 1967;58:618-623

75. Vigliani EC, Cavagna G, Locati G, Foa V. Biological effects of nitroglycol on the metabolism of catecholamines. Arch Environ Health. 1968;16:477-484

76. Agnoletto A, Carnelutti M, Conti M, Foa V. Contributo sperimentale allo studio degli effetti tossico-organolesivi del versenato di calcio e della d-penicillamina. Med Lav. 1963; 54:214226

77. Parmeggiani L, Agnoletto A, Conti M, Foa V, Grisler R. Experimental study on the pathogenesis of nitroglycol poisoning. J Occup Med. 1966;8:152

78. Foà V, Cavagna G, Lacati G, Terzaghi E. Applicazione della penicilloil-polilisina nello studio della sensibilizzazione alla penicillina in operai di una fabbrica di antibiotici. Med Lav. $1966 ; 57: 175-183$.

79. Cavagna G, Foà V, Locati G, Terzaghi M. Ricerche sperimentali sulla tossicologia del metiltetraidroindene. Med Lav. 1966;57:589-605

80. Foà V, Locati G. Su due casi di edema polmonare acuto a insolita eziologia: da acido cloridrico e da candeggianti del commercio (ipoclorito di sodio). Med Lav. 1966;57:655-661

81. Zurlo N. M.A.C. del laboratorio di igiene industriale della clinica del lavoro di Milano. Med Lav. 1969;60:652-665

82. Grieco A, Zurlo N. Postgraduate course on industrial hygiene and ergonomics of Milan politecnico. Med Lav. 1969;60:666-669

83. Zurlo N, Griffini AM Colombo W. Odredivanje olova u mokraći atomskom apsorpcionom spektrometrijom nakon precipitacije torijem. Arh Hig Rada Toksikol. 1969;20:567

84. Bartalini E, Cavagna G Problemi di igiene industriale nell'applicazione della tecnica di spray con torce al "plasma". Med Lav. 1966;57:286-290

85. Ghetti G, Maltoni C, Foà V. Determinazione di due amine aromatiche (benzidina, otolidina) nell'ambiente di lavoro: messa a punto di un metodo. Med Lav 1963;54:655-7 
86. Grisler R, Griffini AM. Semimicrometodo e screening test per la determinazione dell'ALA nell'orina. Med Lav 1970;61:563-568.

87. Grisler R, Griffini AM. Semimicrometodo rapido e screening test per la determinazione dell'acido tricloroacetico nelle orine. Med Lav. 1970;61:509-514.

88. Farina G, Griffini AM, Grisler R. Eliminazione ornaria dello zinco in corso di trattamento con versenato. Med Lav. 1970;61:372-377.

89. Grisler R, Genchi M, Perini M. Determinazione dell'ALA nelle orine mediante analizzatori automatici a flusso continuo e sequenziali. Med Lav. 1969;60:678-686.

90. Grisler R, Farina G. Validità clinica per la diagnosi di saturnismo di un nuovo indice ematologico: la concentrazione eritrocitaria media del piombo. Med Lav. 1969 ;60:360-365.

91. Grisler R, Farina G, Zurlo N, Molteni G. L'impiego del versene per via intramuscolare e a basso dosaggion per il trattamento del saturnismo. Med Lav. 1969;60:288-296.

92. Gambini G, Grisler R. La terapia con xylamide (Milid) della gastro-duodenite dei saturnini. Minerva Med. 1969;60:1017-1023.

93. Capellini A, Grisler R. L'impiego di tests analitici rapidi nella medicina preventiva dei lavoratori. Med Lav. 1967;58:492-500.

94. Frigerio G, Grisler R, Finulli M. Ricerche controllate sull'eliminazione urinaria di alcuni preparati nitrofuranici. Minerva Urol. 1963;15:120-126.

95. Grisler R, Finulli M. Use of the simplified technic of para-aminohippuric acid clearance test in the study of occupational vascular nephropathy. Med Lav. 1960;51:376-380.

96. Porro A, Lorusso L, Falconi B, Colombo A, Galimberti PM, Franchini AF. Mobile miniature X-ray evaluation and pneumoconiosis: the role of the Clinica del Lavoro in Milan (1941-1948). Med Lav. 2018;109 doi: 10.23749/mdl.v109i3.7164.

97. Zurlo N, Griffini AM, Vigliani EC: The content of lead in blood and urine of adults, living in Milan, not occupationally exposed to Lead. Am Ind Hyg Assoc J. 1970;31: 92-95 
98. Griffini AM, Genchi R, Zurlo N. Determinazione rapida della protoporfirina IX eritrocitaria. Med Lav. 1970;61:367-371

99. Foà V, Cavagna G, Manfredi M. Valutazione della piomburia nella diagnosi di intossicazione da piombo tetraetile. Med Lav. 1970;61:491-501

100. Alessio L, Bertazzi PA, Toffoletto F, Foà V. Free erythrocyte protoporphyrin as an indicator of the biological effect of lead in adult males - I. relationship between free erythrocyte protoporphyrin and indicators of internal dose of lead. Int Arch Occup Environ Heath. 1976;37:73-88

101. Alessio L, Bertazzi PA, Monelli O, Foà V. Free erythrocyte protoporphyrin as an indicator of the biological effect of lead in adult males - II. comparison between free erythrocyte protoporphyrin and other indicators of effect. Int Arch Occup Environ Heath. 1976;37:89105

102. Foà V, Gilioli R, Rizzi B, Merluzzi F. L'arseniato di piombo come causa misconosciuta di polineuriti in ambiente rurale: descrizione di due casi clinici. Riv Patol Nerv Ment. $1976 ; 96: 363-377$

103. Foà V, Caimi L, Amante L, et al. Patterns of some lysosomal enzymes in the plasma and of proteins in urine of workers exposed to inorganic mercury. Int Arch Occup Environ Heath. 1976;37:115-124

104. Zurlo N, Patroni M. I M.A.C. per le polveri. Med Lav. 1973;64:181-189

105. Patroni M, Zurlo N. Determinazione gravimetrica delle polveri 'inalabili'. Ann Ist Super Sanità. 1973;9:445-451

106. Cavagna G, Bobbio G. Contributo allo studio delle caratteristiche chimico-fisiche e degli effetti biologici degli effluenti di una fabbrica di alluminio. Med Lav. 1970;61:69-101

107. Foa V, Bertazzi PA. Patologia da cloruro di vinile: stato attuale del problema. Med Lav. 1974;65:401-420 
108. Foa V, Gilioli R. Quadri neurologici da tossici esogeni di attuale utilizzazione industriale. Riv Patol Nerv Ment. 1974;95:795-836

109. Maroni M, Foá V. Editoriale: il 4,4,diaminodifenilmetano: un epatotossico industriale da eliminare. Med Lav. 1975;66:1-4

110. Alessio L, Foa V. Il problema della ipersuscettibilità individuale a inquinanti industriali. Med Lav. 1976;67:211-220

111. Foa V, Gilioli R, Bulgheroni C, Maroni M, Chiappino G. Sulla eziologia delle polineuriti da collanti: indagine sperimentale intorno alla neurotossicità dell n esano. Med Lav. 1976; $67: 136-144$

112. Zurlo N. Igiene industriale nei reparti di lavoro. Med Lav. 1975;66:246-254

113. Cavagna G. Esistono limiti tollerabili per l'assorbimento di sostanze tossiche? Med Lav. 1970;61:137-140

114. Foa V, Carreri V. Sviluppo dei laboratori di analisi nel campo della prevenzione: ambiente di lavoro e controllo degli effetti ambientali. Med Lav. 1976;67:58-72

115. Foa V, Alessio L. Normative igienico sanitarie per polveri di cotone nell'industria tessile. Med Lav. 1973;64:1-7

116. Capellini A, Cavagna G, Nava C. Contributo allo studio della pneumoconiosi da metalli duri. Med Lav. 1970;61:290-301

117. Mocarelli P. Seveso: a teaching story. Chemosphere 2001;43:391-402

118. Maroni M, Colombi A, Gilioli R, et al. Effects of ganglioside therapy on experimental CS2 neuropathy. Clin Toxicol. 1981;18:1475-1484

119. Colombi A, Maroni M, Marasi G, Foa V. La determinazione delle ammine aromatiche totali nelle urine con metodo estrattivo su colonna. Med Lav. 1981;72:514-525

120. Bertolero F, Chiappino G, Foa V, et al. Chromium concentration and histological study in the nasal mucosa of chromium refinery workers. Med Lav. 1981;72:33-37 
121. Andreoletti F, Peruzzo G, Terrana T. Esposizione professionale ad anestetici alogenati in 28 sale operatorie di 5 ospedali di Milano e provincia. Med Lav. 1983;74:277-283

122. Tomasini M, Todaro A, Piazzoni M, Peruzzo GF. Patologia da dimetilformammide: osservazioni su 14 casi. Med Lav. 1983;74:217-220

123. Foà V. Evaluation, limits and perspectives of neurobehavioral toxicology in occupational health. Adv Biosci. 1983;46:173-176

124. Foà V, Maroni M, Ferioli A, Fait A, Colombi A. Microsomal enzyme induction and heme synthesis abnormalities may offer new indicators for biological monitoring in occupational and environmental medicine. Am J Ind Med. 1986;10:105-109

125. Patroni M, Trimarchi R, Andreoletti F, Foa V, Chiappino G. Occupational risk posed by asbestos in the italian asbestos-cement industry. Med Lav. 1987;78:351-359

126. Belli S, Bertazzi PA, Comba P, et al. A cohort study on vinyl chloride manufacturers in Italy: Study design and preliminary results. Cancer Lett. 1987;35:253-261

127. Alcini D, Maroni M, Colombi A, Xaiz D, Foa V. Evaluation of a standardised European method for the determination of cholinesterase activity in plasma and erythrocytes. Med Lav. 1988;79:42-53

128. Barbieri F, Maroni M, Colombi A, Buratti M, Foà V. La correzione per creatinina dell'escrezione urinaria di vanadio e nichel. G Ital Med Lav. 1988;10:65-71

129. Foa V, Riboldi L, Patroni M, Zocchetti C, Sbrana C, Mutti A. Effects derived from longterm low-level chromium exposure in ferro-alloy metallurgy. Study of absorption and renal function in workers. Sci Total Environ. 1988;71:389-400

130. Pezzoli G, Ferrante C, Barbieri S, Zecchinelli A, Foà V. Parkinsonism due to n-hexane exposure. Lancet. 1989;334:874

131. Foa V, Ferioli A. Patologia da microdosi di sostanze chimiche. Med Lav. 1990; 81:11-21

132. Maroni M, Colombi A, Antonini C, Foa V. Urinary D-glucaric acid excretion as a tool for the biological monitoring in occupational medicine. Gen Pharmacol. 1981;12, 2 
133. Colombi A, Maroni M, Antonini C, Fait A, Zocchetti C, Foà V. Influence of sex, age, and smoking habits on the urinary excretion of d-glucaric acid. Clin Chim Acta. 1983;128:349358.

134. Colombi A, Maroni M, Antonini C, Cassina T, Gambini A, Foà V. Low-Ph method for the enzymatic assay of d-glucaric acid in urine. Clin Chim Acta. 1983;128:337-347

135. Colombi A, Maroni M, Ferioli A, Valla C, Coletti G, Foà V. Liquid chromatography of urinary porphyrins for the biological monitoring of occupational exposure to porphyrinogenic substances. Am J Ind Med. 1983;4:551-564

136. Foà V, Colombi A, Maroni M, Buratti M, Calzaferri G. The speciation of the chemical forms of arsenic in the biological monitoring of exposure to inorganic arsenic. Sci Total Environ. 1984;34:241-259

137. Buratti M, Calzaferri G, Caravelli G, Colombi A, Maroni M, Foa V. Significance of arsenic metabolic forms in urine. part I: Chemical speciation. Int $J$ Environ Anal Chem. $1984 ; 17: 25-34$

138. Bertazzi PA, Metelka L, Riboldi L, Guercilena S, Foà V, Dompè M. Valutazione dell'arsenico urinario totale quale indicatore di esposizione professionale. Med Lav. $1982 ; 73: 353-364$

139. Foa V, Buratti M, Calzaferri G, Caravelli G, Colombi A, Maroni M. Valutazione del significato delle forme metaboliche dell'arsenico nell'urina e ottimizzazione delle metodiche analitiche per la loro determinazione. Med Lav. 1982; 73, 3 Suppl:365-380

140. Foa V. L'esposizione professionale a mercurio inorganico: il monitoraggio biologico. $G$ Ital Med Lav. 1980; 2, 3-4:175-179

141. Occella E, Maddalon G, Peruzzo GF, Foa V. Preparazione e caratterizzazione di polveri fini effettuate nella Clinica del Lavoro di Milano a supporto di studi sperimentali. Med Lav. 1999;90:704-721 
142. Maddalon G, Patroni M, Peruzzo GF, et al. Caratterizzazione di polveri e fibre aerodisperse con particolare riguardo alla silice ed agli amianti. Med Lav. 2001;92 (SUPPL.):S5-S101

143. Colosio C, Maroni M, Colombi A, Foa V. Pentaclorofenolo: stato attuale delle conoscenze. Med Lav. 1985;76:273-288

144. Maroni M, Colombi A, Antonini C, Foa V. Health effects after long-term occupational exposure to polychlorinated biphenyl in electrical factories. Toxicol Lett. 1980; 6(SPEC.)

145. Maroni M, Colombi A, Antonini C, Foa V. Health effects of long-term occupational exposure to polychlorinated biphenyls. Dev Toxicol Environ Sci. 1980;8:351-355

146. Maroni M, Colombi A, Cantoni S, Ferioli E, Foa V. Occupational exposure to polychlorinated biphenyls in electrical workers. I. environmental and blood polychlorinated biphenyls concentrations. Br J Ind Med. 1981;38:49-54

147. Maroni M, Colombi A, Arbosti G, Cantoni S, Foa V. Occupational exposure to polychlorinated biphenyls in electrical workers. II. Health effects. Br J Ind Med. 1981; 38, $1: 55-60$

148. Colombi A, Maroni M, Ferioli A, et al. Increase in urinary porphyrin excretion in workers exposed to polychlorinated biphenyls. J Appl Toxicol. 1982; 2, 3:117-121

149. Maroni M, Colombi A, Ferioli A, Foa V. Evaluation of porphyrinogenesis and enzyme induction in workers exposed to PCB. Med Lav. 1984; 75, 3:188-199

150. Ghezzi I, Toffoletto F, Sesana G, et al. Behaviour of biological indicators of cadmium in relation to occupational exposure. Int Arch Occup Environ Health. 1985;55:133-140.

151. Alessio L, Dell'Orto A, Calzaferri G, Buscaglia M, Motta G, Rizzo M. Cadmium concentrations in blood and urine of pregnant women at delivery and their offspring. Sci Total Environ. 1984;34:261-266. 
152. Mussi I, Calzaferri G, Buratti M, Alessio L. Behaviour of plasma and urinary aluminium levels in occupationally exposed subjects. Int Arch Occup Environ Health. 1984;54:155161.

153. Castoldi MR, Calzaferri G, Odone P, Dell'Orto A, Zocchetti C, Alessio L. Behaviour of cadmium biological indicators in subjects living in the Milan area. Med Lav. 1983;74:442452.

154. Alessio L, Castoldi MR, Odone P, Franchini I. Behaviour of indicators of exposure and effect after cessation of occupational exposure to lead. Br J Ind Med. 1981;38:262-267.

155. Forni A, Sciame' A, Bertazzi PA, Alessio L. Chromosome and biochemical studies in women occupationally exposed to lead. Arch Environ Health. 1980;35:139-146.

156. Alessio L, Castoldi MR, Odone P, Franchini I. Behaviour of indicators of dose and effect after cessation of occupational exposure to lead. Dev Toxicol Environ Sci. 1980;8:357-361.

157. Alessio L, Castoldi MR, Monelli O, Toffoletto F, Zocchetti C. Indicators of internal dose in current and past exposure to lead. Int Arch Occup Environ Health. 1979;44:127-132.

158. Alessio L, Cambiaghi G, Croce E, Frigieri P, Trucco R. Determinazione di piombo, cadmio, zinco e ferro nel particolato atmosferico di aree urbane industrializzate della Lombardia. Med Lav. 1979;70:24-37.

159. Alessio L, Castoldi MR, Buratti M, Calzaferri G, Odone P, Ivana C. Confronto fra un metodo estrattivo ed un metodo a lettura diretta per la determinazione fluorimetrica della protoporfirina eritrocitaria. Med Lav. 1978;69:563-575.

160. Alessio L, Bertazzi PA, Monelli O, Toffoletto F. Free erythrocyte protoporphyrin as an indicator of the biological effect of lead in adult males. III. Behavior of free erythrocyte protoporphyrin in workers with past lead exposure. Int Arch Occup Environ Health. $1976 ; 38: 77-86$.

161. Alessio L, Bertazzi PA, Monelli O, Foà V. Free erythrocyte protoporphyrin as an indicator of the biological effect of lead in adult males. II. Comparison between free erythrocyte 
protoporphyrin and other indicators of effect. Int Arch Occup Environ Health. 1976;37:89105.

162. Alessio L, Bertazzi PA, Toffoletto F, Foà V. Free erythrocyte protoporphyrin as an indicator of the biological effect of lead in adult males. I. Relationship between free erythrocyte protoporphyrin and indicators of internal dose of lead. Int Arch Occup Environ Health. 1976;37:73-88.

163. Patroni M. I limiti dimensionali della fibra "respirabile" di asbesto: discussione e proposte. Med Lav. 1983;74:482-491

164. Maddalon G, Patroni M, Peruzzo GF, Trimarchi R. Influenza della comminuzione sulla risposta diffrattometrica nel caolino. Med Lav. 1982;73:237-245

165. Cecchetti GC, Peruzzo GF, Sordelli D. Industrial hygiene programs for workers' health protection in Italy. Am Ind Hyg Assoc J. 1988;49:A373-A376

166. Maroni M, Colombi A, Alcini D, Foà V. Rischi per la salute nell'industria delle biotecnologie. Med Lav. 1987; 78, 4:272-282

167. Peruzzo GF, Sala C. Measurement and characterization of the respirable fraction. Med Lav. 1989; 80, 1:71-77

168. Foà V. Dall'igiene industriale a quella occupazionale ed ambientale. Med Lav. 1989; 80, $1: 6-7$

169. Maroni M, Barbieri F, Colombo MG, La Ferla F. The International Centre for Pesticide Safety. Med Lav. 1990;81:489-493.

170. Maroni M, Fait A, Azimonti G, et al. Programmes and activities of the International Centre for Pesticide Safety. Cent Eur J Public Health. 1995;3:103-106.

171. Maddalon G, Patroni M, Trimarchi R, Clerici C, Occella E. Considerazioni sulla sensibilità, precisione e risoluzione del microscopio ottico nello studio dell'inquinamento dell'ambiente di vita da fibre di amianto. Med Lav. 1991;82:358-371. 
172. Patroni M. Corpuscular pollutants: the problem of particles and fibers (optic microscopy). Med Lav. 1989;80:52-63.

173. Patroni M, Trimarchi R, Andreoletti F, Foà V, Chiappino G. Occupational risk posed by asbestos in the Italian asbestos-cement industry Med Lav. 1987;78:351-359.

174. Fustinoni S, Buratti M, Giampiccolo R, Colombi A. Biological and environmental monitoring of exposure to airbone benzene and other aromatic hydrocarbons in Milan traffic wardens. Toxicol Lett. 1995;77:387-392.

175. Buratti M, Pellegrino O, Valla C, Fustinoni S, Colombi A. Monitoraggio biologico dell'esposizione ambientale a benzene in addetti alla vigilanza urbana. Med Lav. 1997;88:208-219.

176. Fustinoni S, Giampiccolo R, Pulvirenti S, Buratti M, Colombi A. Headspace solid-phase microextraction for the determination of benzene, toluene, ethylbenzene and xylenes in urine. J Chromatogr B Biomed Sci Appl. 1999;723:105-115.

177. Perbellini L, Buratti M, Fiorentino ML, Fustinoni S, Pasini F, Magnaghi S. Matrix interferences in the analysis of benzene in urine. J Chromatogr B Biomed Sci Appl. $1999 ; 724: 257-264$.

178. Carrer P, Maroni M, Cavallo D, et al. Valutazione dell'esposizione personale ad idrocarburi policiclici aromatici ed a benzene, toluene e xileni di lavoratori di una centrale termoelettrica che utilizza olio combustibile denso. Med Lav. 2001;92:314-326.

179. Carrer P, Maroni M, Alcini D, et al. Assessment through environmental and biological measurements of total daily exposure to volatile organic compounds of office workers in Milan, Italy. Indoor Air. 2000;10:258-68.

180. Carrer P, Maroni M, Cavallo D. Allergens in indoor air: environmental assessment and health effects. Int J Immunopathol Pharmacol. 1999;2S:31-32.

181. Carrer P, Maroni M, Cavallo D Allergens in indoor air: environmental assessment and health effects. Sci Total Environ. 2001;270:33-42. 
182. Franchi M, Carrer P. Indoor air quality in schools: the EFA project. Monaldi Archives for Chest Disease 2002;57:120-122.

183. Carrer P, Cavallo D, Maroni M, Foà V. Airborne particles and human health: state of the knowledge and research perspectives. Eur J Onc. 1999;4:545-551.

184. Pastorelli R, Guanci M, Cerri A, et al. Benzo(a)pyrene diolepoxide-haemoglobin and albumin adducts at low levels of benzo(a)pyrene exposure. Biomarkers. 2000;5: 245-251.

185. Colosio C, Maroni M, Barcellini W, et al. Toxicological and immune findings in workers exposed to pentachlorophenol (PCP). Arch Environ Health. 1993;48(2):81-88.

186. Maroni M, Fait A, Colosio C. Risk assessment and management of occupational exposure to pesticides. Toxicol Lett. 1999;107:145-153

187. Colosio C, Barbieri F, Bersani M, Schlitt H, Maroni M. Markers of occupational exposure to pentachlorophenol. Bull Environ Contam Toxicol. 1993;51:820-826.

Formatted: Font: Italic

188. Smith DR. The historical development of academic journals in occupational medicine, 1901-2009. Arch Environ Occup Health. 2009;64: 8-17.

189. Riva MA, Smith DR, Cesana G. Carlo Moreschi (1876-1921): co-founder of the journal "La Medicina del Lavoro" and often forgotten pioneer of modern medicine. Med Lav. 2011;102: 467-472. 


\section{Figure legends}

Figure 1 - The chemistry laboratory of the Clinica del Lavoro at its foundations. A) Clinica del Lavoro side façade, the laboratory was at the first floor; B) Planimetry; C) Chemistry laboratory.

Figure 2 - The industrial hygiene laboratory in the 1960s. A) Chemistry laboratory; B) the sample preparation for the determination of $\mathrm{Pb}$ in blood; $\mathrm{C}$ ) two members of the team performing measurements at the workplace using the mobile unit. Source: Archivio Edison, Centro per la cultura d'impresa. 

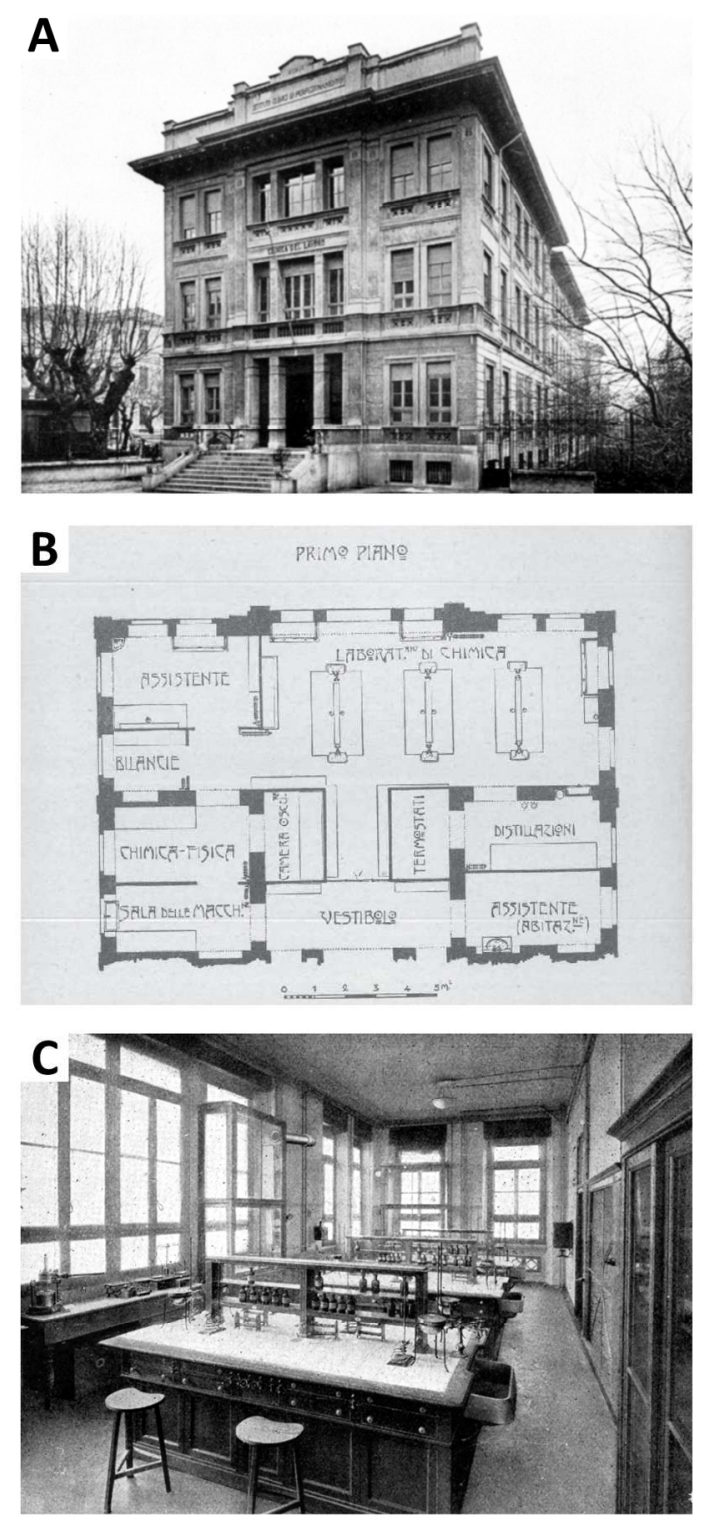

Figure 1 - The chemistry laboratory of the Clinica del Lavoro at its foundations. A) Clinica del Lavoro side façade, the laboratory was at the first floor; B) Planimetry; C) Chemistry laboratory. 

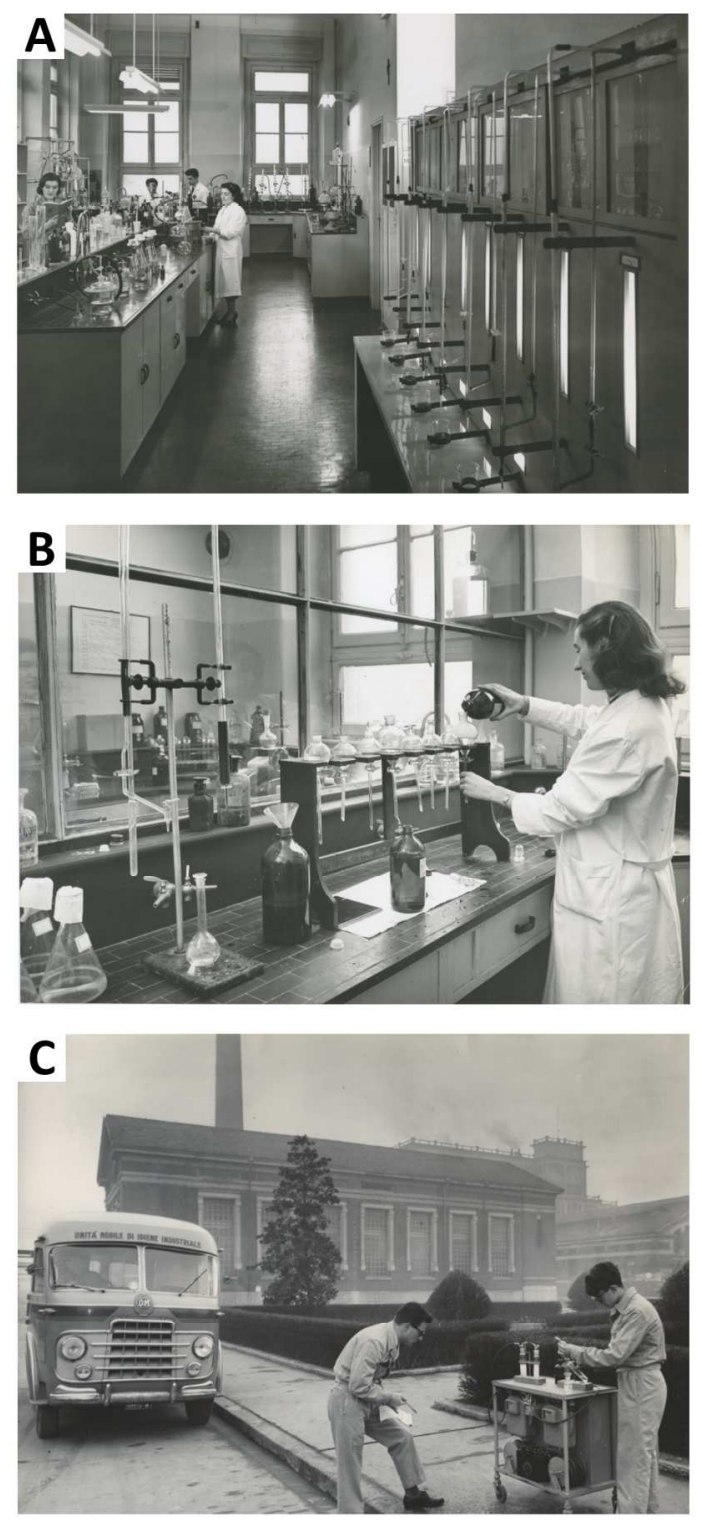

Figure 2 - The industrial hygiene laboratory in the 1960s. A) Chemistry laboratory; B) the sample preparation for the determination of $\mathrm{Pb}$ in blood; $\mathrm{C}$ ) two members of the team performing measurements at the workplace using the mobile unit. Source: Archivio Edison, Centro per la cultura d'impresa. 